\title{
ICCA CONSTITUTION AND BY-LAWS
}

\author{
The Board of ICCA
}

As stated three years ago, the ICCA will publish the Constitution and the By-Laws every three years in order to inform the ICCA members of the formal status of the Association.

The Constitution and By-Laws were first published in the ICCA Newsletter, Vol. 2, No. 2, pp. 18-19 as a proposal. They were approved at the first ICCA Triennial Meeting in Linz, Austria on Sunday, September 28, 1980, during the $3^{\text {rd }}$ World Computer Chess Championship. The last published version appeared in the ICCA Journal, Vol. 12, No. 1, pp. 44-46. Accepted amendments since the first publication are noted below and documented in footnotes as necessary. As published here, the Constitution and By-Laws constitute a draft, to be ratified formally at the 1992 Triennial Meeting in Madrid, Spain. Proposed changes from the previously valid versions have been noted by angle brackets followed by the original text in parentheses. Additions to the valid version have been noted by a doubled pair of angle brackets.

\section{CONSTITUTION}

Article I: Name

The name of this organization shall be the International Computer Chess Association.

\section{Article II: Object}

The organization is a non-profit group devoted to providing an international framework for activities in computer chess and encouraging advances in this field.

\section{Article III: Qualification of Members}

Members in the ICCA are individuals $<<$, honorary members and institutional members $>>.^{1}<$ Individual membership> (Membership) is open to anyone interested in pursuing the objectives of the organization as stated in Article II, who makes application and pays current dues. $<<$ Honorary and Institutional Membership shall be as set forth in the By-Laws.>>

\section{Article IV: Officers and their Election}

The elective officers, their terms $<<$ of office $>$, and their duties shall be as set forth in the By-Laws.

\section{BY-LAWS}

\section{Article I: Membership}

Section 1. General Membership. General Membership shall be as set forth in the Constitution.

Section 2. Honorary Membership. Honorary Membership may be awarded by vote at general meetings to any person who has especially aided the organization.

1 By decision of the 1986 Triennial Meeting in Cologne, West Germany, Institutional Membership has been created next to individual membership (see ICCA Journal, Vol. 8, No. 4, pp. 207-208). 
$<<$ Section 3. Institutional Membership. Institutional Membership can be granted following the request of an organization by the ICCA officers. In particular, chess organizations and computer organizations are eligible.>>

\section{Article II: Meetings}

Section 1. The World Championship and the Triennial Meeting. The ICCA will hold a World Computer Chess Championship every three (3) years<, starting 1980>. (The first championship to be held under ICCA auspices will be in 1980.) The Triennial Meeting will take place during and at the site of the World Championship.

Section 2. Other Meetings. Other meetings of the ICCA may be called from time to time to be held $<$ concurrently > (concurrent) with and at the site of major international computer chess tournaments.

Section 3. Quorum. A quorum at the Triennial Meeting will consist of at least twenty (20) members.

\section{Article III: Officers}

Section 1. Elective Officers. The elective officers of the organization shall consist of a President, VicePresident and Secretary-Treasurer. They shall constitute the Executive Committee of the organization and shall be charged with the administrative affairs of the ICCA.

Section 2. Elections. Elections for the members of the Executive Committee will be held at each Triennial Meeting, with elected officers taking on their duties at the end of that meeting. Nominations are to be made by petition no later than three (3) months before the elections. The ICCA Journal $^{2}$ will announce the candidates at least two (2) months before the election. At least five (5) <members'> (member) signatures are required on each nominating petition. All candidates for election must have been members of the ICCA for no less than two (2) years. Officers are elected by a majority of those present and voting $\langle$ by $\rangle$ (, via) secret, written ballot. Runoffs will be held if no candidate receives a simple majority. The candidate with the least votes will be eliminated from the ballot for each runoff, until one candidate receives the simple majority.

Section 3. Terms of Office. All members of the Executive Committee serve for a three-year term.

Section 4. Executive Committee. The Executive Committee shall be presided over by the President.

\section{Article IV: Standing Committees}

Section 1. Chairmen. Committee Chairmen are appointed for a three-year term by the Executive Committee.

Section 2. Standing Committees. Standing Committees shall be the Publications Board, the Ranking Committee, the Tournament Organizing Committee, the Sanctioning Committee, the Program Rights Committee, the Standards Committee, and the Liaison Committee. $<<$ These committees shall be convened by Council at its discretion as and when required.>>

Section 3. Publications Board. The Publications Board will encourage the publication of technical and non-technical works on the subject of computer chess. The official publication of the ICCA shall be the ICCA Journal. $\ll$ The Triennial Meeting will appoint an Editor-in-Chief of the ICCA Journal to act simultaneously as the committee's chairman of the Publications Board.

2 The original text read "ICCA Newsletter", which has since changed its name. This substitution has been carried out consistently throughout the By-Laws. 
The Editor-in-Chief shall be empowered to nominate Editors and editorial staff as he sees fit, subject only to the provision that Editors must be ICCA members. The Journal may accept acknowledged sponsoring. The Editorial Board is charged with ensuring that the ICCA Journal holds an acknowledged position in the roster of scientific publications. The Advances in Computer Chess Conferences are official ICCA events. The Publications Board is responsible for helping to arrange the publication of the Proceedings of the Advances in Computer Chess Conferences.>>

Section 4. Ranking Committee. The Ranking Committee will establish a rating or ranking system for programs and will rank and rate active programs.

Section 5. Tournament Organizing Committee. The Tournament Organizing Committee will assist local organizers to the degree necessary with ICCA-sanctioned events. This committee will organize the World Championship (see Article II, Section 1 of the By-Laws).

Section 6. Sanctioning Committee. The Sanctioning Committee will give formal ICCA recognition to appropriate events. It will also decide on the time and place of the World Championship subject to Article II, Section 1 of the By-Laws.

Section 7. Program Rights Committee. The Program Rights Committee will decide on matters related to the rights of an individual to use a given program in ICCA-sanctioned events.

Section 8. Standards Committee. The Standards Committee will look into the problem of developing program input/output to facilitate the automation of computer-chess match play.

Section 9. Liaison Committee. The Liaison Committee will seek to establish appropriate ties with other organizations. Any formal ties must be voted upon at the Triennial Meeting (see Article II, Section 1 of the By-Laws).

<<Section 10. Rules Committee. The Rules Committee will be responsible for updating existing rules of play at computer-chess events and for introducing new rules in accordance with experience gained from previous events.>>

\section{Article V: Council}

Section 1. Council Membership. The governing body of the ICCA shall be the Council. The Council shall consist of the President, Vice-President, Secretary-Treasurer and the Chairmen of the Standing Committees.

Section 2. Council Organization. The Council shall be presided over by the President.

\section{Article VI: Dues and Finances}

Section 1. Annual Dues. Dues will be fifty Dutch florins (Hfl. 50.-) or thirty US dollars (\$30.-) per year payable in advance. Dues are collected during the month of January. ${ }^{3}$

Section 2. Disposition of Funds. No part of the net earnings of the ICCA shall ever <accrue> (inure) to or for the benefit of or be distributed to its members, officers or private persons, except that the ICCA shall be empowered to pay reasonable compensation for services rendered, and to make payments and distributions in furtherance of the <express> (exempt) purposes for which it was founded. 


\section{Article VII: Amendment of the By-Laws}

Section 1. Presentation. A request for changes to the By-Laws must be made by written petition of at least five (5) members. Petitions must be made no later than three (3) months before the elections. The ICCA Journal will announce the proposed amendments at least two (2) months before the elections.

Section 2. Voting on Proposed Amendments. Proposed amendments to the By-Laws will become a part of the ballot which includes those running for elected offices. All procedures for voting such a change are the same as for electing officers, except that two-thirds of the members voting and present must support the change.

\section{Article VIII: Dissolution}

Section 1. Dissolution of the ICCA. Upon winding up and dissolution of the ICCA, after paying or adequately providing for the debts and obligations of this organization, the remaining assets shall be distributed to a non-profit fund, foundation, or corporation whose purposes are consistent with the Object of this organization.

\section{ICCA BOARD ELECTIONS}

According to Article III, Section 2 of the ICCA By-Laws (see page 49 of this issue), elections for the members of the Executive Committee of the ICCA (i.e., for its President, Vice-President and Secretary-Treasurer) will be held at the Triennial Meeting during the $7^{\text {th }}$ World Computer Chess Championship in Madrid (November 1992).

Nominations (each requiring at least the signatures of five ICCA members) are to be made by petition no later than three months before the elections. Please send nominations to the ICCA's present President or Vice-President (see inside front cover for addresses). The June issue of this Journal will contain a provisional slate of candidates.

\section{A POTENTIAL ICCA BOARD ADVISOR?}

D. Allan Bromley, the US Presidential Science Advisor, is introduced in the world of

computer chess by our former President Monroe Newborn (Albuquerque, NM, November 1991).

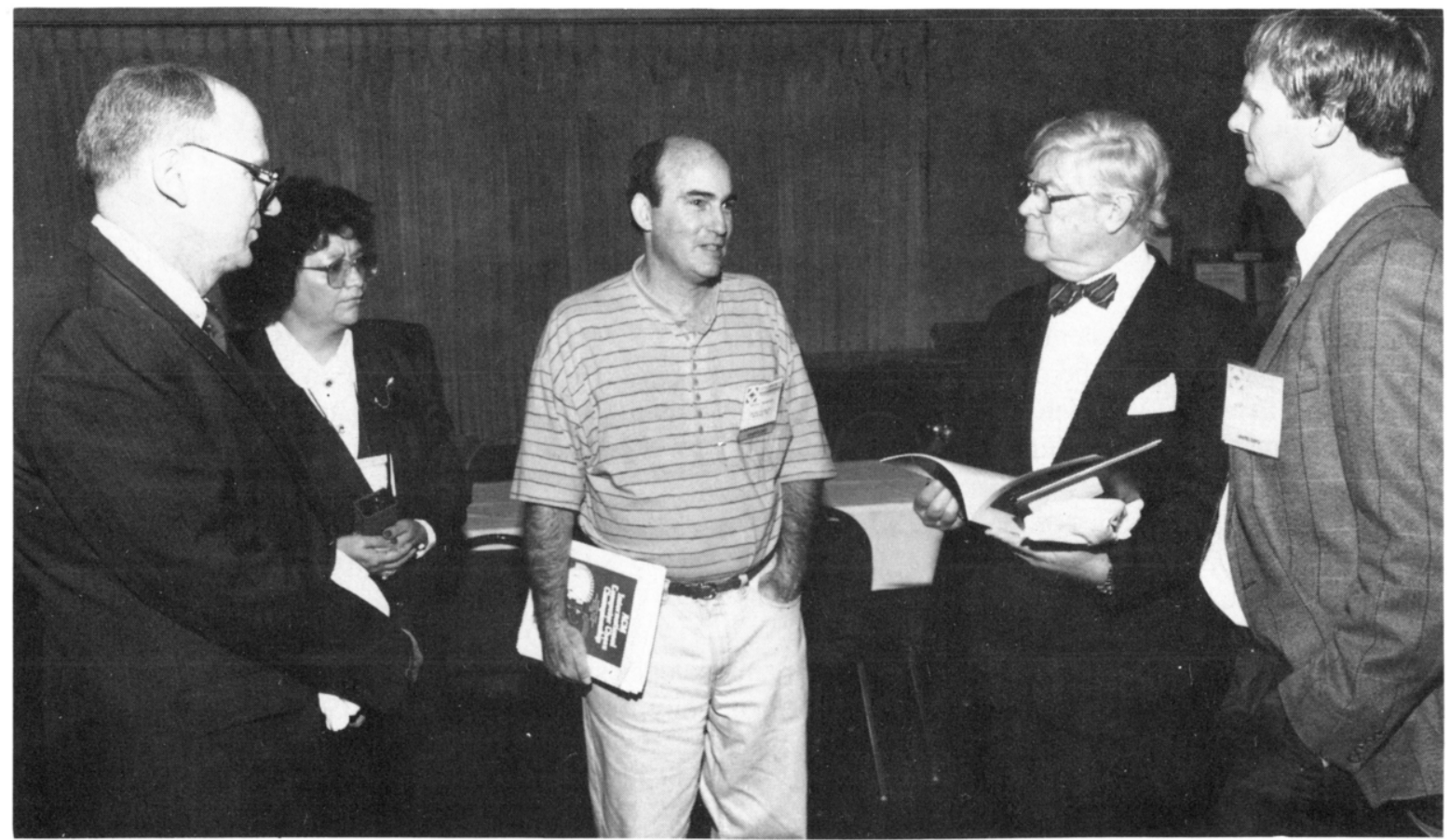

* Terry D. Moore (9901 Blanda N.W., Albuquerque, NM 87114, USA, 505-898-8232) was ACM's

Photo by Terry D. Moore. photographer during the $22^{\text {nd }}$ ACM toumament, November 1991. 